This is an author produced version of a paper published in Accident Analysis \& Prevention. This paper has been peer-reviewed and is proofcorrected, but does not include the journal pagination.

Citation for the published paper:

Lindroos, O., Burström, L. (2010) Accident rates and types among selfemployed private forest owners. Accident Analysis \& Prevention. Volume: 42 Number: 6, pp 1729-1735.

http://dx.doi.org/10.1016/j.aap.2010.04.013

Access to the published version may require journal subscription. Published with permission from: Elsevier

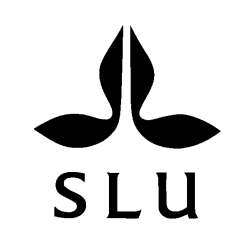

Epsilon Open Archive http://epsilon.slu.se 


\title{
Accident rates and types among self-employed private forest owners
}

\author{
Ola Lindroos ${ }^{1}$ and Lage Burström ${ }^{2}$
}

\author{
${ }^{1}$ Dept of Forest Resource Management, Swedish University of Agricultural Sciences, Sweden \\ ${ }^{2}$ Dept of Public Health and Clinical Medicine, Umeå University, Sweden
}

Published 2010 in Accident Analysis and Prevention 42(6), 1729-1735.

The original publication is available at www.elsevier.com, doi:10.1016/j.aap.2010.04.013 .

\begin{abstract}
Half of all Swedish forests are owned by private individuals, and at least 215000 people work in these privately owned forest holdings. However, only lethal accidents are systematically monitored among self-employed forest workers. Therefore, data from the registries of the Swedish Work Environment Authority, the Labor Insurance Organization and the regional University Hospital in Umeå were gathered to allow us to perform a more in-depth assessment of the rate and types of accidents that occurred among private forest owners.

We found large differences between the registries in the type and number of accidents that were reported. We encountered difficulties in defining "self-employed forest worker" and also in determining whether the accidents that did occur happened during work or leisure time. Consequently, the estimates for the accident rate that we obtained varied from 32 to $>4300$ injured persons per year in Sweden, depending on the registry that was consulted, the definition of the sample population that was used, and the accident severity definition that was employed. Nevertheless, the different registries gave a consistent picture of the types of accidents that occur while individuals are participating in self-employed forestry work. Severe accidents were relatively common, as self-employed forestry work fatalities constituted $7 \%$ of the total number of fatalities in the work authority registry. Falling trees were associated with many of these fatal accidents as well as with accidents that resulted in severe non-fatal injuries. Thus, unsafe work methods appeared more related to the occurrence of an accident than the equipment that was being used at the time of the accident (e.g., a chainsaw). Improvement of the workers' skills should therefore be considered to be an important prevention measure that should be undertaken in this field.

The challenges in improving the safety in these smallest of companies, which fall somewhere between the purview of occupational and consumer safety, are exemplified and discussed.
\end{abstract}

Keywords: Accident statistics; small and medium-sized enterprises (SMEs); micro-companies; leisure-time injuries; chainsaw; firewood.

\section{Introduction}

Half of Swedish forestlands are owned by private individuals (2004a), and at least two-thirds of these individuals (circa 215000 persons) personally conduct work on their forest holdings (Lindroos et al. 2005). This self-employment accounts for 14 million work hours annually, corresponding to half of the total work hours that are conducted in the Swedish forestry industry (Anon 2004a).

In Sweden, self-employed forestry has a long tradition that is rooted in the self-sufficient agrarian culture of the preceding centuries (Törnqvist 1995). However, the current use of the term selfemployment in forestry can give false impressions of people who run their own business for a living, such as self-employed farmers or craftsmen. Selfemployed forestry in Northern Europe seldom provides a living for the people who are involved in it. Instead, it is generally conducted during individuals' leisure time and often makes only a limited contribution to their income (Törnqvist 1995; Ziegenspeck et al. 2004). In a society where most people are gainfully employed, the mentioned conditions have several direct implications for the way in which the work is conducted. First, the activity is self-paced and conducted for the workers' own benefits and, hence, it receives little attention from profit-driven forestry companies or organizations. Second, the 
absence of any employer-employee relationship excludes governmental control.

Motives for undertaking self-employed forestry work include factors such as a tradition of selfemployment and satisfaction derived from actively managing the holding and the physical nature of the work as well as its potential profitability (Ager 1995; Isachsen 1984; Törnqvist 1995). It should, however, also be kept in mind that for some forest owners, this type of self-employment substantially contributes to their household income. For those individuals, self-employed forestry work is often a complement to other economic activities such as farming, which is the most commonly cited additional type of work among self-employed forest workers in both Sweden and Finland (Hämäläinen and Kettunen 2001; Lidestav and Nordfjell 2002).

Self-employed forestry work has a reputation for being an industry with high rates of occupational accidents, but only lethal accidents are systematically monitored (Thelin 2002). The lack of systematic accident reporting leads to unreliable data about accident and injury rates, thereby making accident prevention difficult. The objective of this study was therefore to increase our knowledge of accidents that occur in the self-employed forestry industry through the analysis and comparison of the data that is available in various registries. Moreover, the challenges in improving the safety in these smallest of companies, which fall somewhere between the purview of occupational and consumer safety, are exemplified and discussed.

\section{Materials and methods}

Data regarding accidents that occurred between January 1st 1996 and December 31st 2001 were gathered from the registries of the Swedish Work Environment Authority, the Labor Insurance Organization and the University Hospital in Umeå, Sweden. Data in these registries overlapped to a certain extent but also had differences in the areas and types of injuries they covered.

The Swedish Work Environment Authority is responsible for monitoring Sweden's work environment and work injury statistics. The Work Injury Information System (ISA) contains information about reported work accidents and work-related illnesses from all employees in Sweden. This registry is based on work injury reports that are made to the Social Insurance Office under the Work Injury Insurance Act (LAF). According to the Work Injury Insurance Act, all occupational injuries must be directly reported to the Social Insurance Office by the employer. The registry contained 216000 reports that were made during the study period. The employer is expected to use a special notification form, and all reported occupational injuries are classified. This classification system allowed us to perform a structured search using specific criteria to determine which accidental events were related to self-employed forestry work (Burström et al. 2005). The criteria we used to narrow the search criteria were: 1) self-employed person and 2) branch of business (i.e., forestry and agriculture). Within the overall category of agriculture, accidents were included if forestry-related tools, objects or instruments were involved in the accident (e.g., chainsaw, axe, forwarder, firewood splitter or cutter, timber or twig) or if the accident site or activity was related to forestry work (e.g., logging, silvicultural work or timber transportation).

The Labor Insurance Organization (AFA Insurance) compensates individuals for occupational injuries and is regulated by an agreement between the labor market parties. AFA Insurance administers the insurance policies and provides the services that are decided upon in collective agreements or other types of agreements. The injury information system includes data on all injury reports, medical care and investigations that led to the decision regarding the degree of medical impairment an individual is deemed to have. The registry contained 180000 reports of occupational injuries that occurred during the study period. We identified relevant accidents by searching for incidents involving self-employed individuals who worked in occupations related to forestry and agriculture (e.g., lumberjack, forestry foreman, or farmer) (Lindroos and Burström 2007). We identified 928 incidents that met these criteria, and 193 were selected by searching for 19 different nouns related to forestry work, tools, objects, or instruments (e.g., chainsaw, harvester, saw, log, firewood or forest area).

The University Hospital in Umeå, Sweden, maintains a database of personal injuries within the hospital's service area. The registry contained 60000 reports of accidents that occurred during the study period. Three main criteria were used to narrow down the sample of accidents to those that were potentially related to self-employed forestry work. These criteria were: 1) accident site; 2) injury mechanism; and 3) product code (e.g., farm area, nature/forest area, impact injury due to a fall or due to contact with machines/tools for industry, plants and trees, fuel and wood or typical forestry vehicles) (Wilhelmsson et al. 2004, 2005). Thereafter the medical records were examined twice to identify the cases that were related to self-employed forestry work. From this examination, it appeared that 485 individuals in the Umeå region had received medical attention for injuries that could have occurred 
during self-employed forestry work. A questionnaire was sent to these individuals in 2002 and received responses from 385 people (80\%). Of those, 225 individuals confirmed that the accident had occurred during self-employed forestry work.

\section{Results}

\subsection{Demographic distribution}

During the 6-year study period, 507, 193 and 225 qualifying accidents were found in the authority, insurance and hospital registries, respectively. The mean annual accident numbers were 84.5 (SD 12.5), 32.2 (SD 5.7) and 37.5 (SD 5.2), respectively. Out of the identified accidents, 29 (annual mean 4.8, SD 2.2) were fatal according to the authority data, and 4 (annual mean 0.7, SD 0.5) were fatal according to the insurance data. Fatalities were not included in the hospital registry.

Both the authority and insurance registries contained accidents from all of Sweden's 21 counties. In the authority database, fatalities occurred in 12 different counties, while geographical information was available for only 1 of the 4 fatal accidents in the insurance database. That fatality was, however, reported for a county for which no lethal accidents had been reported in the authority registry.

Most accidents occurred among men, with males accounting for $94.7 \%, 96.4 \%$ and $87.1 \%$ of the accident victims in the authority, insurance and hospital registries, respectively (Fig 1). Most accidents happened to persons who were between 40-49 or 50-59 years of age (Fig 1). All of the reported fatal accidents occurred among men, and the deceased had a mean age of 60 years (range 37-78 years).

\subsection{Accidental events}

The equipment that was most often being used at the time of the accident according to the insurance and hospital registries, respectively, were chainsaws (16\% and 29\%), firewood splitters or cutters (4\% and $32 \%)$ and tractors or other vehicles $(16 \%$ and $9 \%)$. Other kinds of equipment were reported to have been being used when $13 \%$ and $18 \%$ of the accidents occurred, and no equipment was used in $28 \%$ and $6 \%$ of the accidents according to the insurance and hospital databases, respectively. Information on equipment usage was missing for $23 \%$ and $6 \%$ of the accidents, respectively.

The most common events that were stated to have caused workers' injuries were falls, being hit by moving tree parts and coming into contact with machine parts that were in motion (Table 1). Most fatalities were reported to be caused by falling trees, to which $59 \%$ of the fatalities in the authority registry and $75 \%$ of the fatalities in the insurance registry were attributed. Contact with a tree was the external agent that was most commonly reported to have caused an injury or fatality (21\% in the authority database and $28 \%$ of the cases with reported external agent $(n=148)$ in the insurance database). Terrain was reported as the external agent in $11 \%$ and $22 \%$ of the cases in the authority and insurance registries, respectively, while contact with a chainsaw was reported in $7 \%$ and $7 \%$ of the cases, respectively.

\subsection{Injury type and location}

In the authority and insurance registries, most accidents resulted in skeletal injuries, whereas soft tissue injuries were the most common type of injury reported in the hospital registry (Table 2). The head (including the face and eyes) was the most frequently injured anatomical site in the authority database, whereas injuries to the upper extremities were the most common site of injury in the other two databases (Fig. 2). In the hospital registry, almost half (49.3\%) of the injuries were located on upper extremities, and most of those injuries occurred to the fingers (36.4\%). Fingers were injured in $10.5 \%$ and $19.3 \%$ of the accidents that were included in the authority and insurance registries, respectively. Chainsaw injuries to the legs (hip to ankle) constituted $2.7 \%$ of the injuries in the hospital registry.

\subsection{Sick leave}

In the authority registry, accidents resulted in sick leave of an average duration of 55 days. Skeletal injuries resulted in the longest duration of sick leave (mean 109 days), followed by amputations (mean 93 days). Dental injuries resulted in the shortest sick leaves (mean 4 days). When dental injuries were excluded, the average sick leave time increased to 70 days.

About a quarter (24\%) of the accidents in the insurance registry resulted in a sick leave of between 8 and 30 days. A total of $37 \%$ of the accidents resulted in >30 days of sick leave or in financial compensation for pain and suffering, while $37 \%$ of accidents resulted in permanent disability. The remaining $2 \%$ resulted in fatalities.

Sick leave was reported in $29 \%$ of the accidents in the hospital registry, with a mean duration of 43 days.

\section{Discussion}

It has been stated that the expenditure on safety research is inversely correlated with the number of 
accidents that occur within a field of safety research. For example, major hazards (e.g. nuclear power plant safety) and occupational accidents together receive about half of all safety research attention and only account for a small minority of injured persons. On the other hand, home and leisure accidents receive very little research attention and account for about $75 \%$ of injuries (Hale 2006). An accident that is related to home and leisure safety (i.e., consumer safety) normally only causes damage to a very limited number of individuals, but they occur with great regularity and occur in considerable numbers (Hale 2006). Moreover, while safety is typically a low priority in the smallest of companies (Micheli and Cagno 2008), occupational accidents are more common and more severe the fewer employees a company has (Fabiano et al. 2004). Accidents also tend to be more frequent and severe among temporary workers compared to fully employed workers (Fabiano et al. 2008). Consequently, self-employed temporary workers can be said to have high accident rates while only receiving limited research attention. However, in such work settings, the challenges for safety research and extension are greatly accentuated (Hale 2006). In the following discussion of self-employed forestry work in Sweden, a number of problematic conditions that must be addressed when one is dealing with the smallest of companies that fall between occupational and consumer safety will be elucidated.

\subsection{Defining work force and work activity}

The self-employed work that we will be discussing is not well defined with respect to work force or activity. Unlike in occupational settings, this work force cannot be addressed by their employer, work place, or even their occupation. The active workers constitute a large, disorganized and heterogeneous group. Forest owners' associations exist and represent half of the forest land owned by private individuals, but there is little focus on the members' forest work in these associations. Moreover, onethird of the forest owners do not conduct selfemployed work (Lindroos et al. 2005). The Swedish National Board of Forestry's (Anon 2004a) definition of the self-employed forest work force includes the forest owner as well as family members, relatives, employees, neighbors and friends. In the hospital registry, about half (53\%) of the accidents occurred to forest owners, whereas family members accounted for $33 \%$, neighbor/friends for $8 \%$ and relatives for $5 \%$ (Wilhelmson et al. 2004). Consequently, it is the activity that is being performed rather than the ownership or social structure that matters when identifying self-employed forest workers. Consequently, all self-employed forest workers do some sort of work in the forest, but the activities that they perform and their extent of involvement may vary greatly (Lindroos et al. 2005; Wilhelmson et al. 2005).

None of the three registries had self-employed forestry work as pre-defined category, so special selections adapted for the available search terms of each database had to be made. Consequently, the identified work force and activity were inherently different from one another in each database due to differences in definitions and data recording. The authority and insurance registries contained information on occupational accidents, which means that individuals conducting forest work as a means of gainful self-employment (i.e., they were full or parttime foresters) were included, whereas individuals conducting forest work as leisure activity without considering it to be gainful employment were excluded. Moreover, the legal requirement to report occupational accidents to the authorities is probably frequently violated in this field of work, deliberately or unconsciously, because if the injury will not result in financial compensation, there is no incentive to report it to insurance companies. The expected low reporting rates are confirmed by previous studies of both self-employed work in general (Lundqvist and Gustafsson 1992) and of selfemployed forest work (Engsås 1993; Solomon et al. 2006). In fact, it was found that at most $50-60 \%$ of the self-employed forest work accidents were included in the authority registry (Engsås 1993; Solomon et al. 2006). The hospital registry did include all individuals irrespective of their work situation and, hence, also contains more accidents, although only $8 \%$ of its injured persons considered forestry to be their main occupation (Wilhelmson et al. 2004). The leisure time characteristic and the low share of full time activity that forest work comprises for most individuals imply that the work can be considered to be temporary work for most people. Temporary work has previously been found to be a risk factor for occupational injury due to workers' lack of experience as well as their insufficient knowledge and training (Fabiano et al. 2008).

In this study, the forest work that was included was defined as practical forest work (e.g., logging, extraction of logs and silviculture). In addition, firewood processing was included as it has been found to be an important driver for self-employed forest work (Berlin et al. 2006) and is the end of a work sequence that starts with tree felling in the forest. In the hospital registry, firewood processing was the most common activity that was being performed when the accident occurred (it accounted for $54 \%$ of the accidents) (Wilhelmson et al. 2005), whereas such accidents were less frequently re- 
ported in the authority (6\%) (Burström et al. 2005) and insurance registries (4\%) (Lindroos and Burström 2007). The reason that this activity was less commonly reported at the time of injury in the latter two databases is probably due to the registry inclusion requirement of gainful work.

\subsection{Accident severity}

The accidents that occurred while individuals were participating in self-employed forest work were generally found to be severe. Fatalities related to this line of work constituted $6.8 \%$ and $1.8 \%$ of the total number of fatalities in the authority and insurance registries, respectively. Death was the result of $5.7 \%$ and $2.1 \%$ of the self-employed forest work accidents in the authority and insurance registries, respectively, while the overall fatality rates for each registry during the study period were $0.1 \%$ and $0.2 \%$, respectively. Furthermore, accidents among self-employed forest workers resulted in long sick leaves and a high share of permanent disability.

In relation to the geographical region it covers, the hospital registry contained both more accidents and in general less severe ones (e.g., 36\% soft tissue injuries) (Table 2), which was expected because it included accidents of all degrees of severity. The authority and insurance registries, on the other hand, required that injuries be relatively severe to qualify for inclusion. This requirement was often in the form of sick leave duration. However, not even the hospital database is likely to include all injuries that occurred in this line of work. About 5-10\% of individuals who are treated for this type of injury are never reported (Lindström et al. 2002). Additionally, some accidents are treated outside of the emergency department, as a visit to the emergency department is both a function of injury severity and travel distance to the hospital. Relatively minor injuries that occurred far away from the hospital are likely to have been treated at local care centers and thus were not included in the registry. Additionally, in self-employed forestry, only $67 \%$ of injured persons seek medical attention (Neely and Wilhelmson 2006). Moreover, the hospital registry has less extensive coverage of dental injuries, accidents treated by private or company physicians and injuries considered to be untreatable (e.g., lumbago and sprains) than the authority and insurance registries (Larsson and Björnstig 1990). Consequently, large discrepancies between the registries' coverage were expected and have been previously demonstrated; in one study, the authors found that only $20 \%$ of the accidents that qualified for inclusion in all three databases were actually reported to them all (Larsson and Björnstig 1990). Discrepancies were also shown in this study; from the 65 cases in the hospital regi- stry that did result in sick leave should all occupational accidents have been reported to the work authority. However, despite that the hospital registry only covers $55 \%$ of the 142000 inhabitants of the county of Västerbotten (Anon 2006), the authority registry contained only 12 cases from the whole county of Västerbotten. Although the proportion of occupational accidents was unknown and is likely to explain some of the discrepancies between these two registries, it is not likely to explain them all.

Fatal accidents generally are the most accurate of all accident statistics because they are not reported by the injured person, generally involve a certain degree of publicity and should be published in official records (Thelin 2002). Fatalities that occur within the field of forestry are systematically monitored and published annually as official statistics. Although the official records and the authority registry in this study are supposed to come from the same source the numbers of fatalities differed for half of the years, and in total, the authority registry contained one more fatality than the official records for the six-year study period (Anon 2004a). Additionally, the only fatality with geographical attribution in the insurance registry was located in a county for which no fatality was reported in the authority registry. These discrepancies might be few in numbers but are important indicators of the difficulty in assessing accident events in self-employed forestry.

\subsection{Common accidental events}

Despite the differences between the registries, the injuries that were reported during the study period gave a consistent picture of the types of accidents that occur while individuals are participating in selfemployed forestry work. The large number of falls that occurred is probably due to the fact that the work is performed on uneven terrain. Such accidents are seldom reported in forestry, probably because they are not likely to result in severe injuries in comparison to other types of forestry-related accident events. Moreover, falls are probably difficult to prevent because the work inherently must take place on whatever terrain is present.

The chainsaw is associated with a large number of injuries as well as a high degree of injury severity both in professional forestry and in leisure-time forestry activities (Fischer et al. 2005). In this study, chainsaw work was commonly being performed when accidents occurred, but injuries incurred from the chainsaw itself were rare. This finding is in line with previous observations of a decrease in the number of accidents caused by contact with the chainsaw's blades, which has been ascribed to the technological advancements that have occurred in chainsaw design as well as improvements that have 
been made in personal protective gear (Axelsson 1998; Klen and Väyrynen 1984).

However, personal protective gear is not designed to protect the user from the impact of falling trees. Contact with a falling or moving tree was the most common external agent of injury and the second most common accidental event that occurred in this study, which is in line with previous reports of lethal (Anon 2004a; Thelin 2002) and non-lethal forest accidents (Holman et al. 1987; Liss and Sennblad 1989; Neely and Wilhelmson 2006). Lack of control over the direction in which the tree falls has been identified as the main cause of such accidents (Neely and Wilhelmson 2006), and consequently, unsafe (inadequate) work methods seem to be more related to the accidental event itself than the equipment that is used (i.e., the chainsaw). Improvement in workers' skills should therefore be considered to be an important prevention measure.

Firewood processing was found to be related to most accidents in the hospital registry. This particular activity has not often been studied previously, nor has it been considered to be related to forestry accidents. Because it is an activity that is closely related to both self-employment and selfsufficiency, it exemplifies an overseen activity that has a high accident incidence rate, with many severe accidents and deliberate or unconscious violations of safety standards (Lindroos et al. 2008).

\subsection{Accident numbers and incidence rates}

The estimation of accident numbers is a function of the definition that is used for workers, work, accident severity and the accident database used. Despite the previously mentioned limitations and discrepancies that we identified in this study, we will present a number of estimations based on the available data. As indicated in Section 4.2, one accident reported in the authority registry corresponded to 34 accidents reported in the hospital registry (calculated as 12 accidents compared to 225/0.55 accidents), and only two-thirds of injured individuals appeared to seek medical assistance. If one compensates for this underreporting, the 85 accidents per year that were included in the authority registry would imply that 2900 treated accidents $(85 \times 34)$ and 4300 total accidents (2900/0.67) occurred each year. If the accident rate from the hospital database is applied to Sweden's population of 8.9 million inhabitants (Anon 2004b), an estimated 2400 selfemployed forestry work accidents occur annually in Sweden. Both estimates are close to the estimate that was made in the 1990s of 2300-2500 annual accidents (Engsås 1993). Compared to official statistics, the estimates are more than 10 times higher than the number of work accidents reported for the industrial branch of forestry in 2001 (175 accidents) (Anon 2004a), which included both employed and self-employed workers.

Due to our limited knowledge of exposure measures, incidence rates are difficult to deduce. Lindroos et al. (2008) combined a general survey of work hours with number of injured individuals in the hospital registry and found the incidence of accidents that occurred during firewood processing to be high (87 accidents per million work hours). When one combines the mean annual accident numbers from the authority and insurance registries with official statistics of the annual work hours in selfemployed forestry (14.9 million hours and excluding firewood work) (Anon 2004a), the incidence was 5.7 and 2.2 accidents per million work hours for each database, respectively. If the estimations of 2900-4300 accidents per year are used instead and halved to exclude the firewood preparation component, the injury incidence is about 97-144 accidents per million work hours. The latter incidence interval is less than half of that found of the smallest agroindustry firms (Fabiano et al. 2004), but it is in line with findings from temporary workers in the industrial sector (Fabiano et al. 2008).

In forestry and agriculture, workers injure themselves considerably more often while they are working compared to when they are participating in leisure activities (Salminen 2005). This finding might be true for individuals who are gainfully employed within the field of self-employed forestry work, but the application of such terms in these settings would be difficult, mainly because the activity often falls somewhere between work and leisure time and most persons have other gainful employment and therefore may consider their forestry work to be a leisure activity. If it is fully categorized as work, the number of persons working within the forestry sector would increase dramatically along with the number of accidents. On the other hand, if it was categorized fully as leisure time, the many accidents related to self-employed forestry would burden the leisure time side of other work sectors in which these workers are involved.

\subsection{Safety responsibility and prevention measures}

The nature of the work in combination with high accident rates raises the question of safety responsibility that falls somewhere between occupational and consumer safety. Where should the border between the work authority's and the individual's responsibility be drawn in such an ill-defined work situation as self-employed forestry? Given that there is no governmental intention and little public support for forbidding this type of work, the dangers 
will likely remain due to the nature of the work (i.e., the felling and processing of trees). Consumer safety (e.g., technical advances) will therefore not suffice because risk awareness and improved skills (e.g., vocational training) are required to improve on-thejob safety. Until now, neither self-employed forest workers nor the work authority have given the question of work safety much attention. As previously mentioned, the workers are not well organized as a group, leaving the work authority with no counterpart for discussions and little incentive to prioritize safety for this group of workers. Additionally, the borderline location that this type of work occupies between work and leisure makes the cost and benefits of accident prevention indistinct. Nevertheless, it is remarkable that a work force that is accountable for $7 \%$ of the total number of work-related fatalities in Sweden is not better monitored and that there is not an established intervention scheme to improve workplace safety.

As a response to the many accidents, a voluntary education program (a "chainsaw driver's license”) was initiated in 2004 by a consortium of individuals from both forestry and the work authority and has already trained almost 10000 persons in safe and efficient chainsaw use (SäkerSkog 2009). This type of joint endeavor is thought to be one of the most promising intervention measures to improve safety for these workers, and an early evaluation of the intervention indicate both long term knowledge improvement and behavioral change among the participating individuals (Lindroos 2009). However, it will unfortunately be difficult to evaluate the impact of any type of educational intervention on accident rates in this field due to the aforementioned addressed inconsistencies in the currently available accident statistics for self-employed forest workers.

\section{Acknowledgements}

An earlier version of this paper was presented at the $4^{\text {th }}$ International Working on Safety Conference in Crete, Greece, September 30th-October $3^{\text {rd }} 2008$. Financial support for this paper and the three studies on which it is based was provided by the AFA insurance grant T01-03 and the SLO foundation grant SLO-814. The funding sources had no influence on the design, performance, analysis, reporting or publication of the three studies or of this paper. We would like to thank Emma Wilhelmson Aspman, Dianne Wästerlund Staal, Gun Lidestav, Per-Olof Bylund, Eva Malmros and Cecilia Oldertz for their work on the three studies.

\section{References}

Ager, B., 1995. Om självverksamhet, rationalitet och teknikval i småskogsbruket [Self-employment, efficiency and choice of technology in non-industrial private forestry]. Research Notes No 282. Departement of Operational Efficiency, Swedish University of Agricultural Sciences. Garpenberg. [In Swedish with English summary].

Anon, 2004a. Swedish Statistical Yearbook of Forestry 2004. National Board of Forestry. Jönköping, Sweden. [In Swedish]

Anon, 2004b. Statistical Yearbook of Sweden 2004. Statistics Sweden. Stockholm. [In Swedish]

Anon, 2006. Facts about Västerbotten 2006. Västerbotten County Administrative Board and Västerbotten County Council. Umeå.

Axelsson, S.-Å., 1998. The Mechanization of Logging Operations in Sweden and its Effects on Occupational Safety and Health. Journal of Forest Engineering 9:2, 25-31.

Berlin, C., Lidestav, G. and Holm, S., 2006. Values placed on forest property benefits by Swedish NIPF owners: Differences between members in forest owner associations and non-members. Small-Scale Forestry 5:1, 83-96.

Burström, L., Malmros, E., Bylund, P.-O., Wilhelmson, E. and Wästerlund Staal, D., 2005. Anmälda arbetsolyckor under självverksamt skogsarbete [Reported occupational accidents during selfemployed forestry work]. Arbetlivsrapport No 2005:7. National Institute of Working Life. Umeå, Sweden. [In Swedish with English summary].

Engsås, J., 1993. Accidents in Small-scale forestry prerequisites for accident prevention among private wood-lot owners. Research Notes No. 251. Department of Operational Efficiency, Swedish University of Agricultural Sciences. Garpenberg.

Fabiano, B., Currò, F. and Pastorino, R., 2004. A study of the relationship between occupational injuries and firm size and type in the Italian industry. Safety Science 42, 587-600.

Fabiano, B., Currò, F., Reverberi, A. and Pastorino, R., 2008. A statistical study on temporary work and occupational accidents: Specific risk factors and risk management strategies. Safety Science 46, 535-544.

Fischer, V., Young, N., Mueller, C. and Stueland, D. T., 2005. Three times the injuries among occasional wood cutters compared to professional loggers: sample of emergency rooms in central and northern Wisconsin. American Journal of Industrial Medicine 47:3, 246253.

Hale, A. R., 2006. Method in your madness: System in your safety. Delft University of Technology. Delft, The Netherlands.

Holman, R. G., Olszewski, A. and Maier, R. V., 1987. The epidemiology of logging injuries in the Northwest. The Journal of Trauma 27:9, 1044-1050.

Hämäläinen, A. and Kettunen, A., 2001. Self-employment and working methods in delivery sales of timber by Finnish non-industrial private forest owners. TTS Institute's Publications 378. TTS Institute. Helsinki. 
Isachsen, O., 1984. Trade with and use of firewood. Research paper 6. Norwegian Forest Research Institute. Ås, Norway. [In Norwegian].

Klen, T. and Väyrynen, S., 1984. The role of personal protection in the prevention of accidental injuries in logging work. Journal of Occupational Accidents 6:4, 263-275.

Larsson, T. J. and Björnstig, U., 1990. The epidemiology of occupational accidents: three ways to measure the problem in a Swedish municipality. Journal Of Occupational Health \& Safety Australia And New Zealand 6:1, 39-52.

Lidestav, G. and Nordfjell, T., 2002. Med skogsägaren i fokus [With the forest owner in focus]. LRF Skogsägarna. [In Swedish].

Lindroos, O., Lidestav, G. and Nordfjell, T., 2005. Swedish non-industrial private forest owners - selfemployment and equipment investments. Small-Scale Forestry 4:4, 409-426.

Lindroos, O. and Burström, L., 2007. Skadehändelser bland självverksamma privata skogsägare skaderegisteranalyser [Accidents among selfemployed private forest owners - register analysis]. Report 183. Department of Forest Resource Management, Swedish University of Agricultural Sciences. Umeå, Sweden. [In Swedish with Swedish summary].

Lindroos, O., Wilhelmson Aspman, E., Lidestav, G. and Neely, G., 2008. Accidents in family forestry's firewood production. Accident Analysis and Prevention 40:3, 877-886.

Lindroos, O., 2009. Utvärdering av studiecirkelbaserad motorsågskörkortsutbildning [Evaluation of study circle based chainsaw work education]. Report 246. Department of Forest Resource Management, Swedish University of Agricultural Sciences. Umeå, Sweden. [In Swedish with English summary].

Lindström, R., Tegenborg, S., Bylund, P.-O., Björnstig, U. and Eriksson, A., 2002. Kartläggning av personskador orsakade av hund och katt i Umeå "Gå ut med hunden" den aktivitet som oftast var relaterad till skada. Läkartidningen 99, 656-662.

Liss, J.-E. and Sennblad, G., 1989. Work injuries of selfemployed Swedish forest owners 1982-84. Research Notes No. 146. Department of Operational Efficiency,
Swedish University of Agricultural Sciences. Garpenberg. [In Swedish].

Lundqvist, P. and Gustafsson, B., 1992. Accidents and accident prevention in agriculture. A review of selected studies. International Journal of Industrial Ergonomics 10:4, 311-319.

Micheli, G. J. L. and Cagno, E., 2008. Perception of safety issues and investments in safety management in small- and medium-sized enterprises: a survey in the Lecco area. Prevention Today 4:7, 7-18.

Neely, G. and Wilhelmson, E., 2006. Self-reported incidents, accidents, and use of protective gear among small-scale forestry workers in Sweden. Safety Science 44:8, 723-732.

Salminen, S., 2005. Relationships between injuries at work and during leisure time. Accident Analysis \& Prevention 37:2, 373-376.

Solomon, C., Poole, J., Palmer, K. and Coggon, D., 2006. Non-fatal occupational injuries in British agriculture. Occup Environ Med 64, 150-154.

SäkerSkog, 2009. www.sakerskog.se. Access date 200904-29. Last update date 2009-04-24.

Thelin, A., 2002. Fatal accidents in Swedish farming and forestry, 1988-1997. Safety Science 40:6, 501-517.

Törnqvist, T., 1995. Inheritors of the Woodlands. A sociological Study of Private, Non-Industrial Forest Ownership. Report No 41. Department of ForestIndustry-Market Studies, Swedish University of Agricultural Sciences. Uppsala. [In Swedish with English abstract].

Wilhelmson, E., Bylund, P.-O., Burström, L. and Staal Wästerlund, D., 2004. Skadehändelser under självverksamt skogsarbete [Injuries during selfemployed forestry work]. Rapport nr 122. Olycksanalysgruppen, Norrlands universitetssjukhus. Umeå. [In Swedish].

Wilhelmson, E., Staal Wästerlund, D., Burström, L. and Bylund, P.-O., 2005. Public health effects of accidents in self-employed forestry work. Small-scale Forestry 4:4, 427-436.

Ziegenspeck, S., Hardter, U. and Schraml, U., 2004. Lifestyles of private forest owners as an indication of social change. Forest Policy Econ. 6:5, 447-458. 


\section{Tables and Figures}

Table 1. Distribution of causes of reported accidents

\begin{tabular}{lccccc}
\hline & \multicolumn{2}{c}{ Authority } & $(\mathrm{N}=507)$ & & \multicolumn{2}{c}{ Insurance $(\mathrm{N}=148)$} \\
\cline { 2 - 5 } Event & $\mathrm{n}$ & $\%$ & & $\mathrm{n}$ & $\%$ \\
\hline Fall on the same level & 117 & 23.1 & 48 & 32.4 \\
Hit by tree in motion & 119 & 23.5 & 34 & 23.0 \\
Hit by machine in motion & 83 & 16.4 & 17 & 11.5 \\
Hit by flying/falling object (other than tree) & 49 & 9.7 & 14 & 9.5 \\
Handling tool/object & 46 & 9.1 & 22 & 14.9 \\
Over-exertion & 44 & 8.7 & 3 & 2.0 \\
Vehicle/traffic accidents & 22 & 4.3 & 5 & 3.4 \\
Other & 27 & 5.3 & 5 & 3.4 \\
\hline
\end{tabular}

Table 2. Distribution of injury types

\begin{tabular}{|c|c|c|c|c|c|c|}
\hline \multirow[b]{2}{*}{ Injury } & \multicolumn{2}{|c|}{ Authority $(\mathrm{N}=507)$} & \multicolumn{2}{|c|}{ Insurance $(\mathrm{N}=183)$} & \multicolumn{2}{|c|}{ Hospital $(\mathrm{N}=225)$} \\
\hline & $\mathrm{n}$ & $\%$ & $\mathrm{n}$ & $\%$ & $\mathrm{n}$ & $\%$ \\
\hline Bone fracture & 129 & 25.4 & 54 & 29.5 & 48 & 21.3 \\
\hline Dental damage & 117 & 23.1 & $-{ }^{a}$ & $-{ }^{a}$ & $0^{\mathrm{b}}$ & $0^{\mathrm{b}}$ \\
\hline Sprain, strain, distortion & 95 & 18.7 & 24 & 13.1 & 12 & 5.3 \\
\hline Contusion & 65 & 12.8 & 47 & 25.7 & 35 & 15.6 \\
\hline Soft tissue injuries & 40 & 7.9 & 28 & 15.3 & 80 & 35.6 \\
\hline Amputation & 17 & 3.4 & 10 & 5.5 & 15 & 6.7 \\
\hline Concussion/brain injury & 11 & 2.2 & 2 & 1.1 & 2 & 0.8 \\
\hline Nerve, joint, or muscle injuries & - & - & 6 & 3.3 & 12 & 5.3 \\
\hline Other & 33 & 6.5 & 12 & 6.6 & 21 & 9.3 \\
\hline
\end{tabular}

- This injury category was not used in this registry.

${ }^{a}$ Dental damage was included in the insurance registry $(9 \%, n=17)$ but was categorized as fracture $(n=10)$, contusion $(n=4)$ and other $(n=3)$.

${ }^{\mathrm{b}}$ Dental damage was not excluded but was likely under-reported because patients could have consulted dentists without being seen in the hospital's emergency department. 


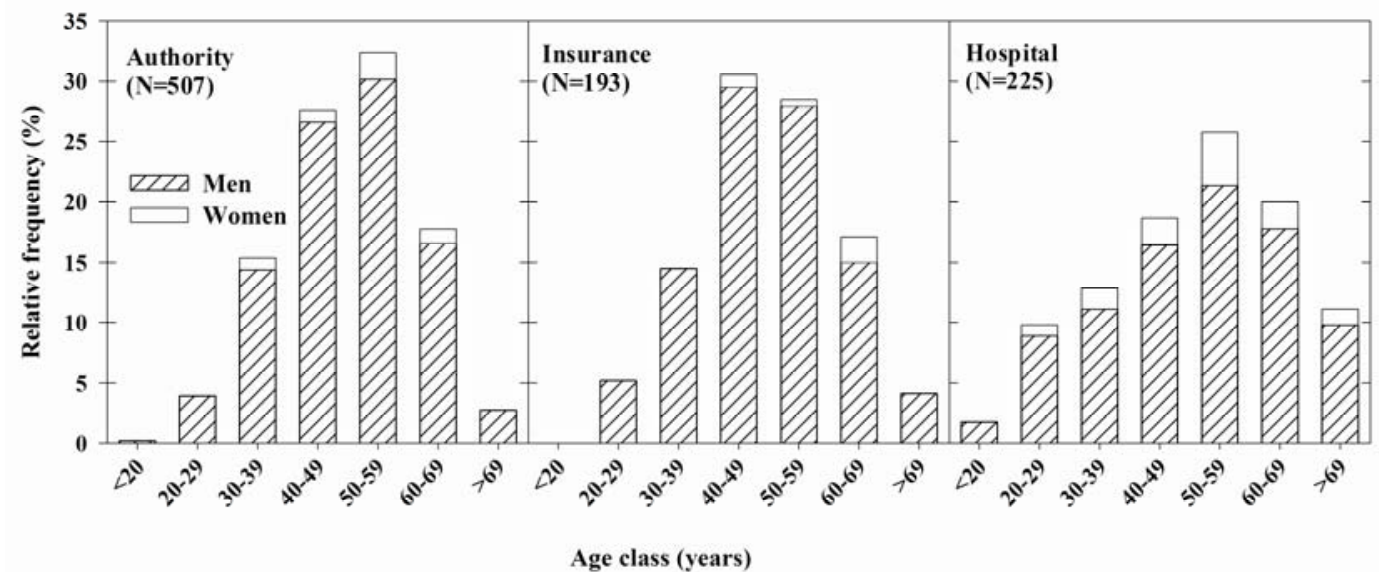

Figure 1. Relative frequency distribution of the number of injured individuals as a function of sex and age.

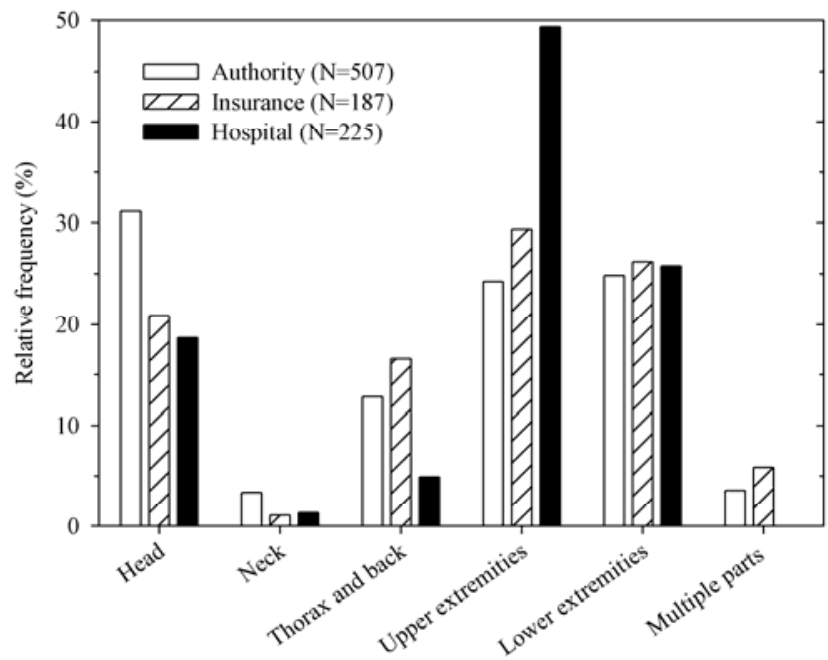

Figure 2. Relative frequency distribution of accidents stratified by main injury location. The location category "multiple parts" was not used in the hospital registry. 